\title{
PENGARUH ASSET STRUCTURE, ASSET QUALITY, CAPITALIZATION, SIZE TERHADAP RETURN ON ASSET PADA PERUSAHAAN PERBANKAN
}

\author{
Rizka Ariyanti \\ Dosen Prodi Akuntansi Politeknik Pusmanu Pekalongan \\ Korespondensi: rizkaariyanti81@gmail.com
}

\begin{abstract}
This study aims to examine and analyze Return On Assets (Studies in Bank Go Public in Indonesia Stock Exchange 2011-2015). To test these variables, the researchers use the 25 companies that went public in Indonesia Stock Exchange. This type of research is explanatory research.. The data used in this research are secondary data from financial statements published by banking companies during 2011-2015. Furthermore, the data collected was analyzed quantitatively using multiple regressi using Eviews program version 8.1. Silmultan The results showed that the variable asset structure, asset quality, capitalization, and size affect Return On Assets (ROA). Indicate that the asset structure is not significant negative on Return On Assets (ROA), variable asset quality significantly negative on financial Return On Assets, variable capitalization significant positive effect on Return On Assets, variable size significantly influence Return On Asset (ROA),
\end{abstract}

Keywords: Asset Structure, asset quality, capitalization, size, return on assets

\section{PENDAHULUAN}

Return on Assets (ROA) menggambarkan kinerja keuangan perusahaan dalam menghasilkan laba bersih dari aktiva yang digunakan untuk operasional perusahaan. ROA digunakan untuk mengetahui kinerja perusahaan berdasarkan kemampuan perusahaan dalam mendayagunakan jumlah aset yang dimiliki, ROA yang semakin bertambah menggambarkan kinerja perusahaan yang semakin baik dan para pemegang saham akan mendapatkan keuntungan dari dividen yang diterima semakin meningkat, atau semakin meningkatnya harga maupun return saham.

Adanya faktor-faktor yang mempengaruhi kinerja keuangan perusahaan menjadi hal yang penting sebagai dasar pertimbangan dalam menentukan komposisi keuangan perusahaan. Dalam penelitian ini, ada beberapa faktor yang akan diteliti yang diduga berpengaruh terhadap Return On Assets diantaranya Asset Struktur, Asset Quality, Capitalization, Size,

Asset structure menuru Ali Kesuma (2009) adalah kekayaan atau sumber-sumber ekonomi yang dimiliki oleh perusahaan yang diharapkan akan memberikan manfaat dimasa yang akan datang yang terdiri dari aktiva tetap, aktiva tidak berwujud, aktiva lancar, dan aktiva tidak lancar. Menurut Riyanto (1993:12) dalam Rina Walmiaty Mardi (2006): "Perbandingan atau perimbangan antara aktiva lancar dan aktiva tetap akan menentukkan struktur kekayaan (struktur aktiva). Struktur aktiva tercermin dalam sisi kiri suatu neraca, yang menunjukkan komposisi aktiva yang harus dibiayai.

Berdasarkan hasil penelitian yang dilakukan penelitian oleh Antonio Trujillo (2012) yang membutihkan bahwa asset structure berpengaruh positif terhadap Return On 
Assets namun ada perbedaan ditingkat signifikasi. Semakin naik struktur aktiva berarti aktiva tetap yang dimiliki perusahaan akan meningkat yang berakibat modal kerja.

Asset Quality suatu yang mampu menimbulkan aliran kas positif atau manfaat ekonomi lainnya. Berdasarkan surat keterangan Direksi Bank Indonesia No.26/22/KEP DIR tanggal 29 Mei 1993 tentang kualitas aktiva produktif, disebutkan bahwa penanaman dana bank pada aktiva produktif wajib sesuai dengan prinsip penanaman dana kesiapan bank dalam menanggung kemungkinan timbulnya risiko kerugian dalam penanaman dana tersebut.

Hasil penelitian Antonio Trujillo (2012) yang membutihkan bahwa Asset Quality berpengaruh negatif signifikan terhadap Return On Asset. Menurut Dian (2011) kualitas aset semua aktiva total rupiah yang dimilik bank dengan maksud untuk memperoleh penghasilan yang diharapkan. Aspek kualitas aset dapat diproksi dengan menggunakan rasio non performing loans dan non perporming asset.

Capitalization Ada asumsi umum dalam literatur yang menyatakan bahwa biaya ekuitas adalah kewajiban bank paling mahal dalam pengembalihan yang diharapkan (Herrero et al 2009 Hakenes dan schnabel, 2011). Berpendapat bahwa persyaratan ekuitas yang lebih tinggi meningkatkan biaya pendanaan karena modal berisiko dan memerlukan pengembalian yang lebih tinggi. Ini akan menjelaskan mengapa bank menunjukkan sedikit antusiasme ketika diminta untuk meningkatkan rasio kecukupan modal mereka. Hasil penelitian oleh Antonio Trujillo (2012) membutikan bahwa capitalization berpengaruh positif dan signifikan terhadap Return On Assets

Size (ukuran perusahaan) investor menanamkan modalnya dengan mempertimbangkan besar kecilnya suatu perusahaan. Besar atau kecilnya suatu perusahaan akan mempengaruhi kemampuan dalam menanggung risiko yang mungkin timbul akibat berbagai situasi yang dihadapi perusahaan berkaitan dengan operasional (Ismail, 2004, h.52).

Mengutip pendapat dari Ismail (2004) penyebab kenaikan dari ukuran perusahaan (Size) dikarenakan ukuran perusahaan yang besar dapat meningkatkan return saham dari perusahaan tersebut. Berdasarkan penelitian oleh Antonio Trujillo (2012) yang membutihkan bahwa size berpengaruh positif signifikan terhadap kinerja keuangan. Jundan Adiwiratama (2012). Hasil penilitian menunjukan bahwa ukuran perusahaan (size) tidak berpengaruh signifikan terhadap Return On Asset.

\section{RUMUSAN MASALAH}

Rumusan masalah dalam penelitian ini yaitu bagaimana pengaruh Assets Strucure, Assets Quality, Capitalization, Size terhadap Return On Assets pada perbankan yang go public di Bursa Efek Indonesia. Adapun pertanyaan penelitian (research questions) yang diajukan dalam penelitian ini adalah sebagai berikut:

1. Bagaimana pengaruh Assets Structure terhadap Return On Assets Perbankan di Bursa Efek Indonesia?

2. Bagaimana pengaruh Assets Quality terhadap Return On Assets Perbankan di Bursa Efek Indonesia?

3. Bagaimana pengaruh Capitalization terhadap Return On Assets di perusahaan Perbankan di Bursa Efek Indonesia?

4. Bagaimana pengaruh Size terhadap Return On Assets Perbankan di Bursa Efek Indonesia? 


\section{RETURN ON ASSET (ROA)}

Return on asset (ROA) merupakan rasio keuangan perusahaan yang berhubungan dengan profitabilitas yang digunakan untuk mengukur kemampuan perusahaan mengahasilkan keuntungan atau laba (profitabilitas) pada tingkat pendapatan, aset dan modal saham tertentu (Hanafi dan Halim, 2003: 27). Semakin besar ROA perusahaan, semakin besar pula posisi perusahaan tersebut dan semakin baik pula posisi perusahaan tersebut dari segi penggunaan aset (Dendawijaya, 2000: 120). Secara matematis ROA dapat dirumuskan sebagai berikut:

Rumus : $R O A=\frac{\text { LabaBersih }}{\text { TotalAsset }} \times 100 \%$

(Dendawijaya, 2005) Antonio Trujillo (2012)

ROA mempunyai hubungan yang positif, karena dengan ROA yang tinggi berarti profitabilitas (laba) juga tinggi. Kondisi seperti itulah yang akan berdampak pada kenaikan harga saham karena pada hakikatnya dalam ekonomi konvesional motif invesatasi adalah memperoleh laba yang tinggi. Dengan rasio keuangan yang baik akan mencerminkan kondisi keuangan yang baik pula, sehingga akan mempengaruhi harga saham (Ang-1997: 34).

\subsection{Pengaruh Assets Structure terhadap Return On Assets}

Aktiva atau aset adalah segala sumber daya dan harta yang dimiliki perusahaan untuk digunakan dalam operasinya. Suatu perusahaan pada umumnya memiliki dua jenis aktiva yaitu aktiva lancar dan aktiva tetap Menurut Weston dan Brigham dalam Husnan (2005:175) struktur aktiva ialah pertimbangan atau perbandingan antara aktiva tetap dan total aktiva. Sedangkan menurut Syamsudin (2007:9) struktur aktiva adalah Penentuan berapa besar alokasi dana untuk masing-masing komponen aktiva, baik dalam aktiva lancar maupun dalam aktiva tetap.

Berdasarkan hasil penelitian yang dilakukan oleh Ali Kesuma (2009) struktur aktiva memiliki pengaruh langsung yang berlawanan dengan harga saham. Semakin naik struktur aktiva berarti aktiva tetap yang dimiliki perusahaan akan meningkat yang berakibat modal kerja dan kemampuan dari perusahaan untuk memenuhi kewajiban perusahaan yang akan jatuh tempo menurun, sehingga perusahaan akan memperlukan modal dari saham, sehingga harga saham akan menurun.

Hubungan ini ada karena peningkatan asset diragukan, yang tidak diperoleh pendapatan membutuhkan bank untuk mengalokasikan sebagian yang signifikan dari laba kotor untuk menutupi kerugian kredit yang diharapkan dengan demikian profitabilitas akan lebih rendah. Diantara penelitian yang menunjukkan hubungan langsung antara profitabilitas dan kualitas asset antara lain Alexiou dan Sofoklis (2009), Athanasoglou et al (2008), Chio Razzo (2008). Penelitian oleh Antonio Trujillo (2012) yang membutikan bahwa struktur aktiva berpengaruh positif terhadap kinerja keuangan. Dengan demikian dapat merumuskan hipotesis sebagai berikut

$\mathrm{H}_{1}$. Terdapat pengaruh positif Asset Structure Terhadap kinerja keuangan. 


\subsection{Pengaruh Asset Quality terhadap Return On Assets}

Menurut Muljono (1995) faktor-faktor yang dapat mempengaruhi besar kecilnya kebutuhan permodalan bank adalah sebagai berikut: Penilaian kualitas aset merupakan penilaian terhadap kondisi aset bank dan kecukupan manajemen risiko kredit Kelangsungan usaha bank tergantung pada kesiapan untuk menghadapi risiko kerugian dari penanaman dana. Oleh sebab itu dalam rangka kesiapan menghadapi risiko kerugian, bank berkewajiban menjaga kualitas aktiva produktimya. Penilaian kualitas aset mencerminkan kemampuan manajemen bank dalam mengelola aktiva produktimya. Bagi bank yang mempunyai tingkat kolektibilitas yang tinggi dan mempunyai earning aset yang memadai maka kebutuhan modalnya akan dapat diperoleh dari laba usaha bank yang bersangkutan, dan sebaliknya apabila bank tersebut rugi terus-menerus maka ada kemungkinan pula modalnya akan terkikis sedikit demi sedikit namun profitabilitas secara langsung berhubungan dengan kualitas asset pada neraca yaitu kualitas kredit yang buruk memiliki nilai negatif. Karena peningkatan asset diragukan, yang tidak diperoleh pendapatan untuk mengalokasikan sebagian yang signifikan dari laba kotor untuk menutupi kerugian kredit yang diharapkan dengan demikian profitabilitas akan lebih rendah.

Di antara penelitian yang menunjukkan hasil penelitian sesuai dengan penelitian oleh Antonio Trujillo (2012) yang membutikan bahwa kualitas asset berpengaruh negatif terhadap kinerja keuangan hubungan langsung antara profitabiltas dan kualitas asset yaitu Alexiou dan Sofoklis (2009), Athanasoglou (2008), Chio-Razzo (2008) dan Deyoung dan Beras (2004).

$\mathrm{H}_{2}$ : Terdapat pengaruh positif Asset Quality terhadap kinerja keuangan.

\subsection{Pengaruh Capitalization terhadap Return On Assets}

Ada asumsi umum dalam literature perbankan bahwa biaya ekuitas adalah kewajiban bank paling mahal dalam pengembalihan yang diharapkan (Herrero et al 2009 Hakenes dan schnabel, 2011). Berpendapat bahwa persyaratan ekuitas yang lebih tinggi meningkatkan biaya pendanaan karena modal berisiko dan memerlukan pengembalian yang lebih tinggi. Ini akan menjelaskan mengapa bank menunjukkan sedikit antusiasme ketika diminta untuk meningkatkan rasio kecukupan modal mereka. Hasil penelitian oleh Antonio Trujillo (2012) membutikan bahwa capitalization berpengaruh positif dan signifikan terhadap kinerja keuangan.

H3 : Terdapat pengaruh positif Capitalization terhadap kinerja keuangan

\subsection{Pengaruh Size terhadap Return On Assets}

Size atau ukuran perusahaan dapat ditunjukkan oleh total aset, total penjualan bersih, rata-rata tingkat penjualan dan rata-rata total aktiva. Semakin besar total aset atau aktiva perusahaan maka semakin besar pula ukuran suatu perusahaan tersebut.

Sebagian besar peneliti menggunakan ukuran perusahaan sebagai proksi sensitifitas politis dan pelaku manajemen dalam melaporkan kinerja keuangan. Zimmerman (1989) menyarankan untuk menggunakan proksi ukuran perusahaan dalam kerangka political cost. Berdasarkan size hypothesis yang dipaparkan oleh Watt dan Zimmerman (1986), berasumsi bahwa perusahaan besar secara politis, lebih besar melakukan transfer political cost dalam kerangka politic process, dibandingkan dengan perusahaan kecil. Lebih lanjut beberapa penelitian berhasil 
membutihkan bahwa politic process memiliki dampak pada pemilihan prosedur akuntansi oleh perusahaan yang berukuran besar. (Watt dan Zimmerman:1986)

Bukti empiris penelitian oleh Antonio Trujillo (2012) yang membutihkan bahwa size berpengaruh positif dan signifikan terhadap kinerja keuangan. Menunjukkan bahwa variabel Size berpengaruh positif dan signifikan terhadap return saham

$\mathrm{H}_{4}$ : Terdapat pengaruh positif Size terhadap kinerja keuangan

Berdasarkan telaah, rasio keuangan perbankan yang sesuai sebagai proksi kinerja perbankan adalah Return On Asset (ROA). Kemudian beberapa faktor yang mempengaruhi kinerja perbankan adalah Asset Structure, Asset Quality, Capitalizaion, dan Size. Berdasarkan teori yang sudah dikemukakan diatas, maka kerangka pemikiran dalam penelitian ini adalah sebagai berikut:

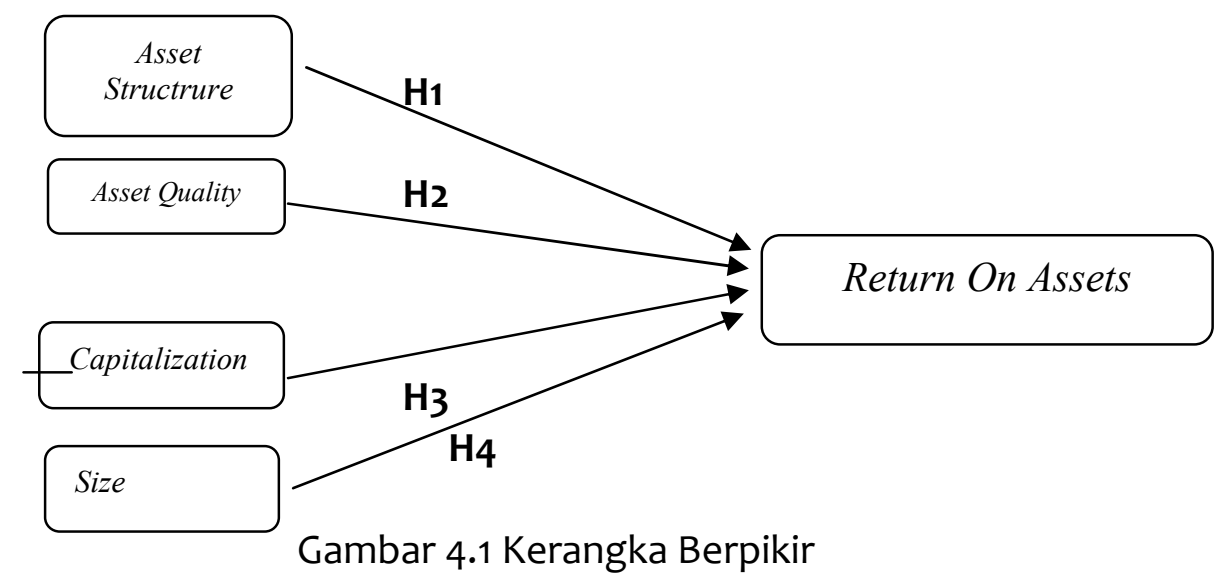

\section{METODE}

Jenis penelitian yang digunakan adalah "Explanatory research" atau penelitian yang bersifat menjelaskan, artinya penelitian ini menekankan pada hubungan antar variabel penelitian dengan menguji hipotesis. Populasi yang ditetapkan dalam penelitian ini adalah data perbankan yang listing di Bursa Efek Indonesia Periode 2011 2015. Populasi dalam penelitian ini seluruh perusahaan pebankan yang terdaftar di Bursa Efek Indonesia dengan kurun waktu 2011-2015. Adapun teknik pengambilan sampel yang digunakan adalah purposive sampling. Metode pengumpulan data yang digunakan, yaitu dengan cara mengumpulkan, mencatat, dan mengkaji data skunder yang berupa laporan keuangan perusahaan perbankan yang dipublikasikan oleh BEI untuk periode $2011-2015$.

\subsection{Definisi Operasional Variabel}

Dalam penelitian ini ada enam variable yaitu Return On Asset ( $\left.Y_{1}\right)$, Assets Structure (X1), Assets Quality ( X2), Capitalization (X3), Size (X4)

\subsection{Assets Structure}

Struktur aktiva atau struktur kekayaan adalah "perimbangan atau perbandingan baik antara aktiva lancar dan aktiva tetap akan menentukan structur kekayaan (struktur aktiva)" relatif antara aktiva lancar dengan aktiva tetap" (Rina Walmiaty Mardi-2006) Sebagian besar literatur perbankan setuju bahwa profitabilitas diharapkan meningkat sebagai portofolio pinjaman yang 
tumbuh dalam kaitannya dengan aset lebih aman lainnya, selama suku bunga pinjaman yang diliberalisasi dan bank berlaku markup ingpric- (GarciaHerreroetal.2009) Struktur aktiva diketahui dengan membandingkan total aktiva tetap dan total aktiva yang memiliki perusahaan. Total aktiva tetap diketahui dengan menjumlahkan rekening-rekening aktiva tetap berwujud perusahaan seperti tanah, gedung, mesin dan peralatan, kendaraan dan aktiva tetap terwujud lainnya kemudian dikurangi akumulasi penyusutan aktiva tetap.

Assets Structure $=$ Loans

Total Aset

\subsection{Assets Quality}

Faktor-faktor yang dapat mempengaruhi besar kecilnya kebutuhan permodalan bank adalah sebagai berikut: Penilaian kualitas aset merupakan penilaian terhadap kondisi aset bank dan kecukupan manajemen risiko kredit Kelangsungan usaha bank tergantung pada kesiapan untuk menghadapi risiko kerugian dari penanaman dana. Oleh sebab itu dalam rangka kesiapan menghadapi risiko kerugian, bank berkewajiban menjaga kualitas aktiva produktimya. Asset Quality merupakan penilian terhadap kualitas kredit macet yang terdapat diperusahan perbankan.

Assets Quality = NPL Gross

\subsection{Capitalization}

Asumsi umum dalam literature perbankan bahwa biaya ekuitas adalah kewajiban bank yang paling mahal dalam pengembalian yang diharapkan

$$
\text { Cap }=\frac{\text { Equity }}{\text { Total Assets }}
$$

\subsection{Firm size}

Size atau ukuran perusahaan dapat ditunjukkan oleh total aset, total penjualan bersih, rata-rata tingkat penjualan dan rata-rata total aktiva. Semakin besar total aset atau aktiva perusahaan maka semakin besar pula ukuran suatu perusahaan tersebut. Semakin besar total aktiva maka semakin besar modal yang ditanam, sementara semakin banyak penjualan maka semakin banyak juga perputaran uang dalam perusahaan. Sehingga dapat dikatakan bahwa ukuran perusahaan merupakan ukuran atau besarnya asset kekayaan yang dimiliki oleh perusahaan.

$$
\text { Size }=\text { Ln Total Assets }
$$

Kajian ini akan menggunakan metode data panel yaitu penggabungan antara data time series dan cross section. Sehingga bentuk fungsi persamaan regresi yang dibuat dalam penelitian ini yaitu :

Persamaan(1): Y1it $=\alpha+\beta_{1} X_{1} i t+\beta_{2} X_{2} i t+\beta_{2} X_{3} i t+\beta_{2} X_{4} i t+$ iteit

Dimana: $\quad Y_{1}=$ Return On Asset ( ROA)

$\mathrm{X}_{1}=$ Asset Structure

$\mathrm{X}_{2}=$ Asset Quality

$\mathrm{X}_{3}=$ Capitalization

$\mathrm{X}_{4}=$ Size

$\mathrm{E}=$ error/residual 


\section{HASIL DAN PEMBAHASAN}

\subsection{Fixed Effect Model (FEM) Variabel Dependen Return On Assets}

\begin{tabular}{crrrr}
\hline \hline Variable & Coefficient & Std. Error & t-Statistic & Prob. \\
\hline \hline SA & -1.518795 & 1.288700 & -1.178548 & 0.2409 \\
SIZE & 1.095514 & 0.168362 & 6.506890 & 0.0000 \\
QA & -0.140235 & 0.023365 & -6.002001 & 0.0000 \\
CAPITALIZATION & 5.919143 & 2.983304 & 1.984090 & 0.0495 \\
C & -6.235964 & 1.649803 & -3.779823 & 0.0002 \\
\hline \hline R-squared & 0.476822 & Mean dependent var & 1.436560 \\
Adjusted R-squared & 0.459383 & S.D. dependent var & 1.751440 \\
S.E. of regression & 1.287776 & Akaike info criterion & 3.382888 \\
Sum squared resid & 199.0039 & Schwarz criterion & 3.496020 \\
Log likelihood & -206.4305 & Hannan-Quinn criter. & 3.428848 \\
F-statistic & 27.34190 & Durbin-Watson stat & 1.085019 \\
Prob(F-statistic) & 0.000000 & &
\end{tabular}

Sumber : Hasil Output Eviews 8.1

\subsubsection{Koefisein Determinasi}

Tampilan output eviews diatas menunjukkan besarnya AdjustedR ${ }^{2}$ sebesar (0.459383), hal ini berarti bahwa 45.93\% variabel Return On Asset (ROA) dapat dijelaskan oleh Asset Structure, Asset Quality, Size, Capitalization. Sedangkan sisanya 54.07 \% dijelaskan oleh variabel lain di luar model ini. Standard error of estimate (SE of Regression) sebesar 1.287776, makin kecil nilai SEE akan membuat nilai regresi semakin tepat dalam memprediksi variabel dependen

5.1.2 Uji Signifikansi Parameter Individual (Uji Statistik t)

Keempat variabel independen yang dimasukan dalam model menunjukkan variabel Asset Quality, Capitalization dan Size berpengaruh terhadap Kinerja Keuangan. Dengan persamaan matematis sebagai berikut:

ROA : $-6.235964+1.095514$ Size+5.919143Cap-0.140235Aq

\subsection{Pengujian Hipotesis Pada Masing-masing Variabel Bebas Terhadap Return On Assets}

Pengujian dalam penelitian ini dilakukan dengan dua tahap uji bagi masingmasing variabel bebas pada model penelitian ini, yaitu uji signifikansi dengan probability $p$-value dan uji arah atas nilai koefisiennya.

\subsubsection{Variabel Asset Structure terhadap Return On Assets}

Uji signifikansi yang dilakukan pada variabel bebas dapat dilihat dari nilai $\mathrm{p}$-value t-stat. Dari hasil regresi didapatkan bahwa dengan tingkat signifikansi 95\% $(a=5 \%)$ variabel Asset Structure memiliki p-value t-stat 0.2409. karena nilai tersebut $>0.05$ maka variabel ini berada pada terima $\mathrm{H}_{\mathrm{o}}$. Sehingga dapat diambil keputusan bahwa variabel Asset Structure merupakan variabel yang tidak mempengaruhi Return On Assets dari perusahaan perbankan. Dikarenakan ada faktor lain selain Asset Structure yang mempengaruhi Kinerja Keuangan di dalam perusahaan perbankan.

Asset Structure menggambarkan jumlah aktiva yang dimiliki oleh perusahaan yang dijadikan sebagai utang dari pihak luar (investor). Kepemilikan jumlah aktiva yang tinggi akan memberikan kepercayaan pihak 
luar (investor) mendapatkan pinjaman dan modal untuk membiayai operasi perusahaan. Hasil penelitian ini tidak sesuai dengan penelitian oleh Antonio Trujillo (2013) yang membutikkan bahwa asset structure berpengaruh positif terhadap Return On Assets namun ada perbedaan ditingkat signifikasi. Rachel Kristiana (2014) yang membutikan bahwa asset structure tidak berpengaruh terhadap kinerja keuangan. Apabila asset structure berpengaruh terhadap kinerja perusahaan, maka perusahaan memiliki keuntungan yang tinggi. Sehingga mampu melunasi utang-utang perusahaan dan keuntungan dapat dialokasikan untuk membayar dividen pemegang saham. Begitu juga sebaliknya apabila assets strucure tidak berpengaruh terhadap kinerja keuangan, maka perusahaan memiliki keuntungan yang rendah sehingga tidak mampu melunasi hutang perusahaan dan keuntungan tidak dapat dialokasikan untuk membayar deviden bagi pemegang saham.

5.2.2. Variabel Asset Quality terhadap Retrun On Assets

Uji signifikansi yang dilakukan pada variabel bebas dapat dilihat dari nilai $\mathrm{p}$-value t-stat. Dari hasil regresi didapatkan bahwa dengan tingkat signifikansi 95\% ( $a=5 \%)$ variabel Asset Quality memiliki p-value t-stat 0.0000 . karena nilai tersebut $<0.05$ maka variabel ini berada pada daerah tolak $\mathrm{H}_{0}$. Sehingga dapat diambil keputusan bahwa variabel Asset Quality merupakan variabel yang mempengaruhi Return On Assets dari perusahaan perbankan. Selanjutnya perlakuan atas uji arah untuk menentukan apakah hubungan antara variabel merupakan hubungan positif atau negatif dengan melihat koefisiennya. Dari ouput hasil regresi menunjukkan bahwa koefisien asset quality bernilai -0.140235. Dari angka tersebut dapat diinterpretasikan bahwa hubungan yang terjadi antara asset quality dengan Return On Assets adalah hubungan yang tidak searah atau negatif. Karena apabila asset quality perusahaan meningkat $1 \%$ maka nilai Return On Assets perusahaan akan menurun senilai $0.14 \%$.

Asset Quality mengambarkan kondisi aset bank dan kecukupan manajemen risiko kredit kelangsungan usaha bank tergantung pada kesiapan untuk mengahadapi risiko kerugian dari penanaman dana. Oleh sebab itu dalam rangka kesiapan menghadapi risiko kerugian, bank berkewajiban menjaga kualitas aktiva produksinya. Hasil penelitian ini sesuai dengan penelitian oleh Antonio Trujillo (2013) yang membutihkan bahwa asset quality berpengaruh negatif dan signifikan terhadap kinerja keuangan. Linda Mufidatur Rofiqoh (2014) yang membutikan bahwa asset qulity berpengaruh negatif terhadap kinerja keuangan. Mengambarkan kondisi aset bank dan kecukupan manajemen risiko kredit kelangsungan usaha bank tergantung pada kesiapan untuk menghadapi risiko kerugian dari penanaman dana. Oleh sebab itu dalam rangka kesiapan mengahadapi risko kerugian, bank berkewajiban menjaga kualitas aktiva produksinya. Penilaian kualitas aset mencerminkan kemampuan manajemen bank dalam mengelola aktiva produksinya.

\subsubsection{Variabel Capitalization terhadap Return On Asset}

Uji signifikansi yang dilakukan pada variabel bebas dapat dilihat dari nilai p-value t-stat. Dari hasil regresi didapatkan bahwa dengan tingkat signifikansi 95\% ( $a=5 \%$ ) variable Capitalization memiliki p-value t-stat 0.0495 . karena nilai tersebut $<0.05$ maka variabel ini berada pada daerah tolak $\mathrm{H}_{\mathrm{o}}$. 
Selanjutnya perlakuan atas uji arah untuk menentukan apakah hubungan antara variabel merupakan hubungan positif atau negatif dengan melihat koefisiennya. Dari ouput hasil regresi menunjukkan bahwa koefisien capitalization bernilai 5.919143. Dari angka tersebut dapat diinterpretasikan bahwa hubungan yang terjadi capitalization dengan Return On Assets adalah hubungan yang searah atau positif. Karena apabila capitalization perusahaan meningkat 1\% maka nilai Return On Assets perusahaan akan menurun senilai $5.91 \%$.

Herrero et al 2009 Hakenes dan Schnabel, 2011. Berpendapat bahwa persyaratan ekuitas yang lebih tinggi meningkatkan biaya pendanaan karena modal berisiko dan memerlukan pengembalian yang lebih tinggi. Ini akan menjelaskan mengapa bank menunjukkan sedikit antusiasme ketika diminta untuk meningkatkan rasio kecukupan modal mereka. Hasil penelitian ini sesuai dengan penelitian oleh Antonio Trujillo (2013) yang membutihkan bahwa capitalization berpengaruh positif signifikan terhadap Return On Assets. Hal ini menggambarkan bila biaya modal perusahaan ditingkatkan maka memperlukan pengembalian yang lebih tinggi sehingga pihak manajemen akan berusaha keras agar biaya modal tersebut kembali secepat mungkin dengan demikian maka Return On Assets juga akan meningkat.

5.2.4. Variabel Size terhadap Return On Assets

Uji signifikansi yang dilakukan pada variabel bebas dapat dilihat dari nilai p-value t-stat. Dari hasil regresi didapatkan bahwa dengan tingkat signifikansi 95\% (a=5\%) variabel Size memiliki p-value t-stat 0.0000. karena nilai tersebut $<0.05$ maka variabel ini berada pada tolak $\mathrm{H}_{0}$. Sehingga dapat diambil keputusan bahwa variabel Size merupakan variabel yang mempengaruhi Return On Assets dari perusahan perbankan. Selanjutnya perlakuan atas uji arah untuk menentukan apakah hubungan antara variabel merupakan hubungan positif atau negatif dengan melihat koefisiennya. Dari ouput hasil regresi menunjukkan bahwa koefisien size bernilai 1.095514. Dari angka tersebut dapat diinterpretasikan bahwa hubungan yang terjadi antara size dengan Return On Assets adalah hubungan yang tidak searah atau negatif. Karena apabila size perusahaan meningkat $1 \%$ maka nilai Return On Assets perusahaan akan menurun senilai $1.09 \%$.

Salah satu ukuran kemampuan perusahaan dalam mendapatkan laba yang maksimal dapat dilihat dari rasio-rasio yang menunjukkan perkembangan atau kemunduruan dari operasional norma perusahaan tersebut hal ini dapat dilihat salah satunya dari rasio pertumbuhan dimana rasio pertumbuhan menunjukkan ukuran kenaikan atau penurunan kinerja suatu perusahaan dapat dilihat dari perbandingan satu tahun dan sesudah maupun sedang berjalan. Hasil penelitian ini sesuai dengan penelitian oleh Antonio Trujillo (2013) yang membutihkan bahwa size berpengaruh positif signifikan terhadap kinerja keuangan. 


\section{SIMPULAN}

Pada persamaan regresi berganda $(\mathrm{Y})$, yaitu menganalisis tentang pengaruh variabel asset structure, variabel asset quality, capitalization, dan size terhadap Return On Assets. Hasil temuan penelitian ini menemukan bahwa variabel asset structure memiliki pengaruh negatif tidak signifikan terhadap variabel Return On Assets, variabel asset quality memiliki pengaruh negatif signifikan terhadap Return On Assets, variabel capitalization memiliki pengaruh positif signifikan terhadap Return On Assets, variabel size memiliki pengaruh positif signifikan terhadap Return On Assets

\section{DAFTAR PUSTAKA}

Antonio Trujillo, Ponce. 2013. "What Determinies The Profitability Of Bank?" Evidance From Spain. Accounting \& Finance Vol 53. Issue. 2. PP561-586

Asbi Rachman Faried (2008) “Analisis Pengaruh Faktor Fundamental dan Nilai Kapitalisasi Pasar Terhadap Return Saham Perusahaan Manufaktur Di BEI Periode 2002 s.d 2006.

Baltagi, Bagi (2005). Econometric Anlysis of Panel Data, Third Edition.

Bursa Efek Indonesi, Data Bank, http://idx.co.id/.

Christina Dwi Astuti (2004), Pengaruh Kinerja Keuangan Terhadap Return Saham Pada Perusahaan Manufaktur Yang Terdaftar di Bursa Efek Jakarta.

Dendawijaya (2005). Manajemen Perbankan. Edisi kedua. Jakarta: Ghalia Indonesia.

Khizer. Dkk (2011) "Bank-Specific Macroeconomic Indicators of Profitability- Emprical Evidence from the Commercial Bank of Pakistan".

Kasmir (2005:10), Manajemen Perbankan

Gujarti dan Porter. (2009). Dasar-Dasar Ekonometrika. Jakarta : Salemba Empat

Munawir (2002:31) Tujuan Tentang Analisis Informasi Keuangan, Edi Pertama, Liberty, Yogyakarta.

Nunky Rizky Mahapsari (2013) “Pengaruh Profitabilitas,Struktur Aktifa, dan Pertumbuhan Penjualan Terhadap Harga Saham dengan Struktur Modal Sebagai Variabel Intevening Pada Perusahaan Manufaktur Di Bursa Efek Indonesia"

Rina Walmiati Mardy. (2008). Analisa Faktor-Faktor Yang Mempengaruhi Praktik Peralatan Laba (Income Smoothing) Pada Perusahaan Manufaktur Dan Keuangan Yang Terdaftar Di BEI (2006-2009).

Riyanto, B. 2001. Dasar-dasar Pembelanjaan Perusahaan. Edisi Keempat. Universtitas Masa. Yogyakarta.

Peraturan Bank Indonesia No.26/22/KEP DIR tanggal 26 Mei 1993 tentang kualitas aktiva produktif.

Shocrul R, Ajja, dll. (2011). Cara cerdas menguasai Eviews. Jakarta : Salemba empat.

Sutrisno. 2003. Manajemen Keuangan: Teori, konsep, konsep, dan aplikasi. Edisi Pertama.Ekonisia.Yogyakarta

Undang-undang RI Nomor 10 tahun 1998 tanggal 10 November 1998 tentang perbankan.

Undang-undang Pokok Perbankan nomor 7 tahun 1992 dan ditegaskan lagi denga keluarnya Undang-undang RI. Nomor 10 tahun 1998 tentang jenis perbankan. 